\title{
HUBUNGAN KADAR SENG (Zn) RAMBUT DENGAN Z-SCORE PANJANG BADAN MENURUT UMUR (PB/U) BALITA USIA 12-24 BULAN
}

\author{
Mursid Tri Susilo, Nurmasari Widyastuti*) \\ Program Studi Ilmu Gizi Fakultas Kedokteran Universitas Diponegoro \\ Jl.Dr.Sutomo No.18, Semarang, Telp (024) 8453708, Email : gizifk@undip.ac.id
}

\begin{abstract}
Background : Stunting is a short stature condition as a result of linear growth disorders that characterized by Length for Age Z-score (LTA) <-2 SD. Hair zinc level indicate chronic zinc level in the long term so that appropriate for measuring zinc level on the condition of stunting malnutrition that has lasted a long time. The aim of this research is to investigate the relationship between hair zinc ( $\mathrm{Zn}$ ) level and Length for Age Z-score (LTA) among toddlers aged 12-24 months so it can be a reference to explain the zinc level measuring as an indicator of stunting prevalence biochemically .

Method : An observational study with cross-sectional design on 58 toddlers aged 12-24 months in East Semarang. Subjects were recruited by consecutive sampling. Dietary intake data acquired using a $3 x 24$ hours food recall. Hair zinc level were measured by Atomic Absorption Spectrophotometry (AAS). Bivariate analysis used Pearson and Rank-Spearman.

Results : There were 36,21 \% of stunted toddlers (<-2 SD). All of subjects had a normal hair zinc level (198,61 \pm 49,73 ppm) and there wasn't relationship between hair zinc level and Length for Age Z-score (LTA) ( $r=-0,069$; $p=0,607)$.

Conclusion : There wasn't relationship between hair zinc level and Length for Age Z-score (LTA) ( $r=-0,069$; $p=0,607$ ).
\end{abstract}

Keywords : hair zinc level; length for age Z-score (LTA); stunting

ABSTRAK

Latar Belakang : Stunting merupakan keadaan tubuh yang pendek sebagai akibat dari pertumbuhan linear yang terhambat, ditandai dengan z-score panjang badan menurut umur (PB/U) kurang dari -2 SD. Kadar seng rambut dapat menggambarkan kadar seng kronis pada masa lampau sehingga tepat untuk mengukur kadar seng pada kondisi stunting yang merupakan kondisi malnutrisi yang sudah berlangsung lama. Tujuan penelitian ini adalah untuk mengetahui hubungan kadar seng (Zn) rambut dengan z-score panjang badan menurut umur $(P B / U)$ balita usia 12-24 bulan sehingga dapat menjadi acuan dalam menjelaskan pengukuran kadar seng (Zn) rambut sebagai indikator kejadian stunting secara biokimia.

Metode : Penelitian observasional dengan desain cross sectional, jumlah subjek 58 balita usia 12-24 bulan di kecamatan Semarang Timur. Pengambilan sampel dilakukan dengan consecutive sampling. Data asupan makanan diperoleh menggunakan food recall $3 \times 24$ jam. Kadar seng rambut diukur dengan metode Atomic Absorption Spectrophotometry $(A A S)$. Analisis bivariat menggunakan uji Pearson dan Rank-Spearman.

Hasil: Angka kejadian balita stunting (<-2SD) yaitu 36,21\%. Semua subjek memiliki kadar seng rambut normal $(198,61 \pm 49,73$ ppm) dan tidak terdapat hubungan antara kadar seng $(Z n)$ rambut dengan $z$-score $P B / U(r=-$ $0,069 ; p=0,607)$.

Kesimpulan : Kadar seng $(Z n)$ rambut tidak berhubungan dengan z-score $P B / U(r=-0,069 ; p=0,607)$.

Kata Kunci : kadar seng rambut; z-score PB/U; stunting

\section{PENDAHULUAN}

Upaya perbaikan gizi dihadapkan pada masalah gizi makro dan mikro. Defisiensi seng (Zn) merupakan masalah gizi mikro yang belum sepenuhnya teratasi, hal ini ditunjukkan dengan angka kejadian defisiensi seng yang tinggi di Indonesia. Sebesar 17,3 \% penduduk di dunia mengalami defisiensi seng pada tahun 2005, sementara itu $32 \%$ balita Indonesia mengalami defisiensi seng pada tahun 2006 . $^{1,2,3}$
Seng adalah mineral esensial yang berperan dalam sintesis, sekresi, dan kontrol hormon pertumbuhan (Growth Hormon). Rendahnya sintesis hormon pertumbuhan dapat menghambat pertumbuhan linier dan diduga menyebabkan kondisi stunting pada masa balita. ${ }^{4,5,6}$ Stunting merupakan keadaan tubuh yang pendek sebagai akibat dari pertumbuhan linear yang terhambat, ditandai dengan $z$-score panjang badan menurut umur $(\mathrm{PB} / \mathrm{U})$ kurang dari $-2 \mathrm{SD}^{7,8}$ Keadaan stunting digunakan sebagai indikator

${ }^{*}$ Penulis Penanggungjawab 
masalah gizi kronis yang muncul akibat dari kurang gizi yang sudah berlangsung lama atau penyakit infeksi yang terjadi sehingga memerlukan waktu bagi balita stunting untuk tumbuh dan berkembang serta pulih kembali. ${ }^{9}$ Anak stunting cenderung sulit mencapai potensi pertumbuhan dan perkembangan optimal secara fisik maupun psikomotorik yang erat kaitannya dengan kemunduran kecerdasan dan produktivitas. ${ }^{10}$

Prevalensi balita stunting di Asia Tenggara tergolong tinggi yaitu sebesar $29,1 \%$ pada tahun 2007 sedangkan Indonesia sebesar 35,6 \% pada tahun 2010. ${ }^{11,12}$ Menurut Riskesdas 2010, prevalensi balita stunting pada tahun 2010 di Provinsi Jawa Tengah adalah 33,9 \% sedangkan Pemantauan Status Gizi (PSG) Jawa tengah pada tahun 2010 menunjukkan prevalensi balita stunting di Semarang sebesar $27,5 \% .^{12,13}$

Kuantitas dan kualitas zat gizi yang terasup di dalam makanan akan sangat menentukan pertumbuhan dan perkembangan balita oleh karena itu makanan harus dapat memenuhi kebutuhan gizi balita. ${ }^{14,15}$ Pertumbuhan balita juga berhubungan dengan berat bayi saat lahir. Penelitian yang dilakukan di Tanzania menyebutkan bahwa bayi dengan berat lahir rendah merupakan faktor risiko stunting. ${ }^{16}$

Penelitian mengenai hubungan kadar seng dengan $z$-score $\mathrm{PB} / \mathrm{U}$ masih terbatas dimana masih terdapat hasil yang tidak konsisten. Penelitian pada balita usia 0-36 bulan di Palestina menyatakan bahwa terdapat hubungan yang kuat antara kadar seng serum dengan $z$-score $\mathrm{PB} / \mathrm{U}$ dimana prevalensi kadar seng serum yang rendah (defisiensi) pada balita stunting (z-zcore $<-2 \mathrm{SD}$ ) lebih tinggi dibandingkan dengan balita nonstunting (z-score $\geq-2 S D$ ) yaitu masing-masing sebesar $70,1 \%$ dan $11,6 \% .^{17}$ Namun penelitian pada balita usia 6-59 bulan di Nusa Tenggara Barat, Indonesia menunjukkan hasil yang berbeda yaitu tidak ada hubungan kadar seng serum dengan z-score $\mathrm{PB} / \mathrm{U}^{18}$

Kadar seng tubuh dapat diketahui dengan mengunakan biomarker kadar seng rambut. Analisis kadar seng rambut lebih tepat menggambarkan kadar seng kronis pada masa lampau sehingga tepat untuk mengukur kadar seng pada kondisi stunting yang merupakan kondisi malnutrisi yang sudah berlangsung lama. Kadar seng serum tidak selalu menggambarkan secara tepat kadar seng tubuh karena tergantung pada kadar albumin. Selain itu, pengambilan sampel seng rambut akan menghindari risiko invasif yang mungkin terjadi pada pengambilan serum seng. ${ }^{6,19,20}$

Penelitian seng rambut pada balita masih terbatas dan jarang dilakukan. Sementara itu penelitian kadar seng rambut pernah dilakukan pada anak sekolah dasar usia 6-9 tahun oleh Arindha 2012 yang menyatakan ada hubungan kadar seng rambut dengan derajat stunting yang ditentukan berdasarkan z-score TB/U. Z-score TB/U meningkat dengan meningkatnya kadar seng rambut. ${ }^{21} \quad$ Angka prevalensi balita stunting tertinggi di kota Semarang terjadi di wilayah kecamatan Semarang Timur yaitu sebesar 40,2 \% (96 balita stunting). ${ }^{22}$

Subjek penelitian ialah balita usia 12-24 bulan karena usia tersebut merupakan tahapan golden period disaat pertumbuhan terjadi sangat pesat dan kritis sehingga zat gizi mikro seng memiliki peran yang besar dalam proses pertumbuhan linear. ${ }^{23}$ Penelitian ini bertujuan untuk mengetahui hubungan kadar seng ( $\mathrm{Zn}$ ) rambut dengan $z$-score $\mathrm{PB} / \mathrm{U}$ balita usia 12-24 bulan.

\section{METODE}

Penelitian menggunakan rancangan cross sectional yang melibatkan balita usia 12-24 bulan di wilayah kerja puskesmas Bugangan, kecamatan Semarang Timur, kota Semarang. Populasi target penelitian ini adalah balita dengan usia 12-24 bulan. Populasi terjangkau adalah balita usia 1224 bulan di kelurahan Bugangan, kelurahan Mlatiharjo, dan kelurahan Kebon Agung di wilayah kerja puskesmas Bugangan, kecamatan Semarang Timur, kota Semarang. Dari 3 puskesmas yang ada di wilayah kecamatan Semarang Timur, dipilih 1 puskesmas secara acak untuk mewakili seluruh puskesmas yang ada yaitu puskesmas Bugangan. Wilayah kerja puskesmas Bugangan yaitu kelurahan Bugangan, kelurahan Mlatiharjo, dan kelurahan Kebon Agung.

Pengambilan subjek penelitian dengan melakukan pengambilan data secara consecutive sampling pada balita usia 12-24 bulan. Pengumpulan data karakteristik sampel menggunakan kuesioner meliputi nama, jenis kelamin, tanggal lahir, penyakit infeksi yang diderita, dan berat badan lahir. Pengukuran tinggi badan menggunakan Microtoise dengan panjang maksimal $200 \mathrm{~cm}$ dan tingkat ketelitian $0,1 \mathrm{~cm} .{ }^{24,25}$ Pengolahan data menggunakan software WHO Anthroplus untuk penentuan status gizi balita.

Subjek minimal yang dibutuhkan dalam penelitian adalah 52 balita. Kriteria inklusi dalam 
penelitian ini adalah usia subjek penelitian minimum 12 bulan dan maksimum 24 bulan serta orang tua dari subjek penelitian bersedia mengisi informed consent. Kriteria eksklusi penelitian yaitu subjek penelitian tidak dapat ditemui karena alasan tertentu sehingga data tidak lengkap, mengundurkan diri pada saat penelitian sedang berlangsung, atau meninggal.

Sampel rambut yang digunakan yaitu rambut kepala bagian occipital (kepala bagian belakang) sepanjang $1,5-3 \mathrm{~cm}$ dari kulit kepala dengan total berat rambut per sampel yaitu 0,3-0,5 gram. ${ }^{26}$ Pemeriksaan kadar seng rambut dengan menggunakan metoda Atomic Absorption Spectrophotometry (AAS) dengan alat spectrophotometer Perkin Elmer dilakukan di laboratorium Fakultas Matematika dan Ilmu Pengetahuan Alam Program Studi Kimia Universitas Diponegoro. Pemeriksaan ini dilakukan oleh petugas laboratorium.

Pengumpulan data asupan zat gizi makro (energi, protein, dan lemak) dan asupan zat gizi mikro (seng, besi, kalsium, dan vitamin A) diperoleh melalui wawancara menggunakan food recall 24 jam selama tiga hari tidak berturut-turut. Analisis data menggunakan program komputer. Uji korelasi Pearson digunakan untuk menguji hubungan kadar seng rambut dengan $z$-score $\mathrm{PB} / \mathrm{U}$.

\section{HASIL PENELITIAN \\ Karakteristik Subjek Penelitian}

Penelitian ini melibatkan 58 balita usia 1224 bulan sebagai subjek penelitian di Kelurahan Bugangan, Kelurahan Mlatiharjo, dan Kelurahan Kebon Agung, Kecamatan Semarang Timur. Jumlah balita laki-laki sebanyak $23(39,7 \%)$ dan balita perempuan $35(60,3 \%)$ dengan rata-rata usia subjek penelitian adalah 17,98 $\pm 3,63$ bulan. Ratarata $z$-score $\mathrm{PB} / \mathrm{U}$ subjek penelitian yaitu $-1,26$ $\pm 1,40 \mathrm{SD}$ dengan angka kejadian balita stunting sebanyak 21 (36,21\%). Rata-rata berat badan lahir balita stunting adalah $3,01 \pm 0,33 \mathrm{~kg}$ sedangkan balita normal adalah $3,19 \pm 0,51 \mathrm{~kg}$. Hasil analisis uji Pearson menunjukkan bahwa tidak ada hubungan antara berat badan lahir dengan z-score $\mathrm{PB} / \mathrm{U}(\mathrm{r}=0,210 ; \mathrm{p}=0,114)$.

Tabel 1. Karakteristik subjek penelitian

\begin{tabular}{|c|c|c|c|c|c|}
\hline \multirow{3}{*}{ No } & \multirow{3}{*}{ Karakteristik } & \multicolumn{4}{|c|}{ Kategori Stunting } \\
\hline & & \multicolumn{2}{|c|}{ Stunting $(\mathrm{n}=21)$} & \multicolumn{2}{|c|}{ Normal $(n=37)$} \\
\hline & & $\mathrm{n}$ & $\%$ & $\mathrm{n}$ & $\%$ \\
\hline \multirow[t]{3}{*}{1} & Jenis kelamin & & & & \\
\hline & - Laki-laki & 8 & 38,1 & 15 & 40,5 \\
\hline & - Perempuan & 13 & 61,9 & 22 & 59,5 \\
\hline \multirow[t]{3}{*}{2} & Penyakit infeksi diare & & & & \\
\hline & - Diare & 2 & 9,5 & 1 & 2,7 \\
\hline & - Tidak diare & 19 & 90,5 & 36 & 97,3 \\
\hline \multirow[t]{3}{*}{3} & Penyakit infeksi ISPA & & & & \\
\hline & - ISPA & 5 & 23,8 & 5 & 13,5 \\
\hline & - Tidak ISPA & 16 & 76,2 & 32 & 86,5 \\
\hline
\end{tabular}

\section{Kadar Seng (Zn) Rambut}

Nilai rata-rata kadar seng rambut pada subjek penelitian yaitu $198,61 \pm 49,73 \mathrm{ppm}$ dengan kadar seng rambut terendah 121,34 ppm dan tertinggi 374,40 ppm. Nilai rata-rata kadar seng rambut balita stunting yaitu 198,32 $\pm 55,67$

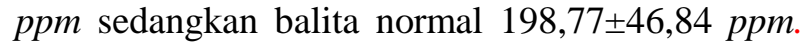

Semua subjek dalam penelitian ini memiliki kadar seng rambut normal ( $\geq 100 \mathrm{ppm}){ }^{27}$ Hasil analisis uji Pearson menunjukkan bahwa tidak ada hubungan antara kadar seng rambut dengan $z$-score $\mathrm{PB} / \mathrm{U}(\mathrm{r}=-0,069 ; \mathrm{p}=0,607)$. Deskripsi dari asupan makanan subjek penelitian ditampilkan pada tabel 2.

Tabel 2. Gambaran Asupan Makanan Berdasarkan Kategori Stunting

\begin{tabular}{lcc}
\hline \multirow{2}{*}{ Variabel $($ mean \pm SD) } & \multicolumn{2}{c}{ Kategori Stunting } \\
\cline { 2 - 3 } & Stunting $($ mean \pm SD) & Normal (Mean \pm SD) \\
\hline Asupan energi & $884,34 \pm 184 \mathrm{kkal}$ & $1052,93 \pm 179 \mathrm{kkal}$ \\
$991,89 \pm 197 \mathrm{kkal}$ & & \\
\hline
\end{tabular}




\begin{tabular}{lcc}
\hline $\begin{array}{l}\text { Asupan protein } \\
34,99 \pm 10,14 \text { gram }\end{array}$ & $32,86 \pm 8,90$ gram & $38,40 \pm 9,7$ gram \\
\hline $\begin{array}{l}\text { Asupan lemak } \\
45,31 \pm 12,48 \text { gram }\end{array}$ & $40,67 \pm 14,11$ gram & $47,95 \pm 10,79$ gram \\
\hline $\begin{array}{l}\text { Asupan seng } \\
4,40 \pm 1,49 \text { miligram }\end{array}$ & $3,65 \pm 1,30$ miligram & $4,82 \pm 1,44$ miligram \\
\hline $\begin{array}{l}\text { Asupan besi } \\
7,82 \pm 6,81 \text { miligram }\end{array}$ & $5,60 \pm 3,42$ miligram & $9,07 \pm 7,90$ miligram \\
\hline $\begin{array}{l}\text { Asupan kalsium } \\
557,99 \pm 287,27 \text { miligram }\end{array}$ & $455,97 \pm 255,41$ miligram & $615,90 \pm 291,39$ miligram \\
\hline $\begin{array}{l}\text { Asupan vitamin A } \\
754,26 \pm 915,30 \text { mikrogram }\end{array}$ & $504,98 \pm 206,85$ mikrogram & $895,74 \pm 1116,19$ mikrogram \\
\hline
\end{tabular}

\section{PEMBAHASAN}

Angka kejadian stunting pada penelitian ini adalah sebanyak 21 balita $(36,21 \%)$. Angka tersebut lebih rendah dari data Dinas Kesehatan Kota Semarang pada tahun 2011 yang menyatakan prevalensi stunting di kecamatan Semarang Timur sebesar 40,2\%. ${ }^{22}$ Angka kejadian balita stunting dalam penelitian ini menunjukkan bahwa kejadian stunting masih tinggi pada balita usia 12-24 bulan. Angka tersebut bahkan lebih tinggi dari data prevalensi stunting Jawa Tengah sebesar 33,9\% dan Indonesia 35,6 \%. Hal ini menunjukkan bahwa wilayah kecamatan Semarang Timur termasuk dalam wilayah dengan angka kejadian stunting tinggi di Indonesia.

Angka kejadian stunting balita perempuan $(61,9 \%)$ lebih tinggi daripada balita laki-laki $(38,1 \%)$. Hasil penelitian ini sesuai dengan penelitian pada balita usia 1-5 tahun di Nusa Tenggara Barat, dimana prevalensi stunting balita perempuan $(51,7 \%)$ lebih tinggi daripada balita laki-laki $(48,3 \%) .{ }^{18}$ Kondisi stunting yang terjadi pada balita tidak lepas dari faktor penyakit infeksi yang berlangsung lama sehingga mempengaruhi proses pertumbuhan dan perkembangan balita. Penyakit infeksi yang terjadi merupakan salah satu penyebab terjadinya stunting pada balita. ${ }^{9}$ Masalah infeksi sering ditemui di dalam sebuah masyarakat. Hubungan timbal balik antara penyakit infeksi dengan balita stunting dapat dilihat secara luas bahwa Infeksi Saluran Pernafasan Akut (ISPA) sering menyertai balita stunting. Penyakit diare dengan mudah terjadi pada anak dengan daya tahan tubuh yang lemah, apabila hal ini terjadi secara terus-menerus maka berisiko terjadinya stunting. ${ }^{28}$

Berdasarkan data riwayat penyakit infeksi selama 3 bulan terakhir, angka kejadian diare balita stunting $(9,5 \%)$ lebih tinggi daripada balita normal $(2,7 \%)$ begitu pula dengan angka kejadian ISPA balita stunting $(23,8 \%)$ lebih tinggi daripada balita normal $(13,5 \%)$. Hal ini mendeskripsikan bahwa angka terjadinya penyakit infeksi diare dan ISPA pada balita stunting lebih tinggi daripada balita normal.

Berat badan saat lahir dikaitkan dengan proses pertumbuhan yang akan terjadi. Hal ini sejalan dengan penelitian yang dilakukan di Tanzania bahwa bayi dengan berat lahir rendah merupakan faktor risiko terjadinya stunting, namun penelitian yang dilakukan di Semarang Timur ini menunjukkan hasil yang berbeda. ${ }^{16}$ Rata-rata berat badan lahir balita stunting $(3,01 \pm 0,33 \mathrm{~kg})$ sedangkan balita normal $(3,19 \pm 0,51 \mathrm{~kg})$. Nilai kedua rata-rata tersebut lebih tinggi dari batas Bayi Berat Lahir Rendah 2500 gram dengan risiko tinggi terjadinya stunting. Analisis statistik menunjukkan bahwa tidak ada hubungan antara berat badan lahir dengan kategori stunting $(\mathrm{r}=$ $0,210 ; p=0,114)$.

\section{Asupan Zat Gizi}

Jumlah (kuantitas) dan mutu (kualitas) zat gizi yang terasup di dalam makanan akan sangat menentukan pertumbuhan dan perkembangan balita, oleh karena itu makanan harus dapat memenuhi kebutuhan gizi balita. ${ }^{14,15}$ Rata-rata asupan protein balita stunting (32,86 $\pm 8,90$ gram) dan balita normal $(38,40 \pm 179$ gram) diatas angka kecukupan protein populasi balita usia 12-24 bulan menurut AKG (26 gram). Hal ini menunjukkan bahwa rata-rata subjek penelitian tidak mengalami defisiensi asupan protein. Pertumbuhan tinggi badan balita salah satunya dipengaruhi oleh asupan protein. Asam amino essensial yang terkandung di dalam protein dibutuhkan untuk pertumbuhan dan imunitas tubuh. Asam amino ini tidak dapat disintesis oleh tubuh sehingga harus disuplai dari makanan. ${ }^{29}$

Rata-rata asupan seng balita stunting (3,65 $\pm 1,30 \mathrm{mg}$ ) di bawah angka kecukupan seng 
populasi balita usia 12-24 bulan menurut AKG (4 $\mathrm{mg}$ ), sedangkan rata-rata asupan seng balita normal $(4,82 \pm 1,44 \mathrm{mg})$ di atas kecukupan AKG. Data tersebut menunjukkan bahwa rata-rata asupan seng balita stunting mengalami defisiensi asupan seng dibandingkan dengan balita normal. Asupan seng yang optimal mendukung proses pertumbuhan, fungsi imunitas, dan pembentukkan tulang. ${ }^{30}$

Rata-rata asupan zat besi balita stunting $(5,60 \pm 3,42 \mathrm{mg})$ di bawah angka kecukupan zat besi populasi balita usia 12-24 bulan menurut AKG (7 mg), sedangkan rata-rata asupan zat besi balita normal $(9,07 \pm 7,90 \mathrm{mg})$ diatas kecukupan AKG. Hal ini menunjukkan bahwa rata-rata asupan zat besi balita stunting mengalami defisiensi dibandingkan dengan balita normal. Asupan zat besi yang rendah memungkinkan terjadinya anemia defisiensi besi. Dampak anemia gizi besi pada balita dihubungkan dengan terganggunya fungsi kognitif, perilaku dan pertumbuhan. $^{31}$

\section{Hubungan Kadar Seng (Zn) Rambut dengan Z- score $\mathrm{PB} / \mathrm{U}$}

Hasil penelitian ini menunjukkan bahwa angka kejadian balita stunting (z-score < -2 SD) sebesar 36,21\% namun semua subjek penelitian memiliki kadar seng rambut normal $(\geq 100 \mathrm{ppm}$ ) dengan rata-rata $198,61 \pm$ 49,73 ppm. Rata-rata kadar seng (Zn) rambut balita stunting $(198,32 \pm 55,67$ SD) sedangkan balita normal $(198,77 \pm 46,84$ SD). Analisis statistik menyatakan bahwa tidak terdapat hubungan antara kadar seng ( $\mathrm{Zn}$ ) rambut dengan $z$-score $\mathrm{PB} / \mathrm{U}(\mathrm{r}=-0,069 ; \mathrm{p}=$ 0,607).

Hasil penelitian sebelumnya tahun 2012 yang dilakukan di daerah Pati dengan subjek anak sekolah usia 6-9 tahun menemukan hubungan signifikan antara kadar seng rambut dengan $z$-score TB/U. Perbedaan hasil penelitian ini dapat terjadi karena perbedaan usia subjek yang diteliti. Penelitian ini dilakukan pada subjek berumur 1224 bulan, sedangkan penelitian sebelumnya dilakukan pada subjek berumur 6-9 tahun. Usia erat kaitannya dengan pertumbuhan pada anak, dimana $z$-score $\mathrm{TB} / \mathrm{U}$ menjadi salah satu indikator paling praktis dan cukup akurat untuk mengidentifikasi pertumbuhan seorang anak, disamping indikator $z$-score berat badan menurut tingi badan (BB/TB). Z-score $\mathrm{PB} / \mathrm{U}$ menjadi satusatunya indikator untuk menginterpretasikan keberhasilan pertumbuhan pada usia balita. Umur merupakan salah satu dasar dalam menentukan nilai $z$-score $\mathrm{PB} / \mathrm{U}$ individu, sehingga perbedaan umur subjek pada dua penelitian tersebut dapat mengakibatkan perbedaan hasil analisis dimana terdapat hubungan signifikan antara kadar seng rambut dengan $z$-score TB/U pada anak SD usia 69 tahun namun tidak terdapat hubungan signifikan antara kadar seng rambut dengan z-score $\mathrm{PB} / \mathrm{U}$ pada balita usia 12-24 bulan.

Tidak adanya hubungan yang signifikan antara kadar seng rambut dengan z-score $\mathrm{PB} / \mathrm{U}$ pada balita usia 12-24 bulan ini, dapat diakibatkan oleh karakteristik rambut yang diambil sebagai objek penelitian. Rambut dipilih sebagai indikator kecukupan seng dalam tubuh karena sel-sel rambut memiliki simpanan seng yang paling banyak dibandingkan dengan bagian lain pada tubuh seperti kuku, kulit maupun serum darah sehingga kadar seng akan lebih mudah terdeteksi, namun penggunaan sampo rambut, konsumsi obat-obatan maupun suplemen tidak ditelaah lebih lanjut dalam penelitian ini sehingga menjadi salah satu keterbatasan yang mengakibatkan data seng rambut menjadi tidak objektif sebagai gambaran kecukupan seng pada balita.

Penelitian di Palestina tahun 2010 pada balita usia 1-3 tahun juga meneliti tentang hubungan kadar seng dengan kejadian stunting. ${ }^{17}$ Akan tetapi, penelitian tersebut menggunakan kadar seng serum dalam darah sebagai indikator stunting. Hubungan signifikan ditemukan antara kadar seng dalam darah dengan kejadian stunting pada anak usia 1-3 tahun. Penggunaan kadar serum sebagai indikator kecukupan seng pada balita cukup mempengaruhi hasil yang diperoleh. Pengambilan darah oleh tenaga kesehatan terlatih (petugas laboratorium), serta tidak adanya paparan kontaminasi dari luar tubuh menjadikan hasil signifikan lebih bisa terlihat dibandingkan pada penelitian dengan menggunakan rambut sebagai indikator kecukupan seng tubuh.

Pengukuran kadar seng rambut dapat digunakan untuk mendeteksi adanya defisiensi mineral seng di dalam tubuh. Kadar seng di dalam tubuh dapat digambarkan melalui kadar seng di dalam rambut, begitu pula dengan konsentrasi paparan mineral seng lain yang bersumber dari luar tubuh misalnya debu, kotoran, atau sampo rambut. Adanya paparan asing tersebut mengakibatkan kadar seng rambut lebih tinggi dari keadaan seharusnya. Selain itu, terjadi efek paradoksal antara kadar seng rambut dengan kadar seng darah. Pada kondisi defisiensi seng di dalam darah, tidak selalu ditunjukkan melalui defisiensi kadar seng rambut. Perubahan kandungan seng rambut lebih lambat daripada perubahan seng dalam darah. Respon perubahan konsentrasi seng dalam rambut 
terjadi pada periode 6 minggu atau kurang, sejak terjadinya perubahan kronis status seng pada manusia. Kadar seng darah sangat cepat berubah seiring dengan konsumsi yang mengikuti pola diurnal, serta kondisi fisiologis seseorang. Oleh karena itu, interpretasi kadar seng rambut harus dilakukan dengan hati-hati. Pemeriksaan kadar seng rambut lebih baik dilakukan bersamaan dengan pemeriksaan kadar seng darah dalam menginterpretasikan kemungkinan defisiensi seng. ${ }^{32}$

Pemilihan rambut sebagai indikator kecukupan seng memiliki keuntungan dibandingkan serum darah yaitu menghindari risiko invasif pada subjek penelitian dan kepraktisan bagi peneliti. Pemilihan indikator sangat dipengaruhi oleh karakteristik subjek dan pertimbangan-pertimbangan lain untuk memperlancar jalannya penelitian dengan tetap mempertimbangkan kualitas data yang diperoleh. Faktor lain yang mempengaruhi panjang badan balita seperti faktor genetik tidak dapat dikontrol di dalam penelitian ini. Analisis dengan melibatkan sel-sel atau jaringan tubuh yang lebih kompleks seperti DNA memungkinkan hasil penelitian yang lebih baik dalam menunjukkan faktor yang mempengaruhi panjang badan balita.

Belum ada indikator yang paling baik dan paling valid untuk menggambarkan kecukupan seng, oleh karena itu diperlukan instrumen pengambilan dan pengolahan data simpanan seng di dalam tubuh dengan sensitivitas yang lebih baik agar tetap bisa dipakai selama penelitian dengan subjek yang berbeda tanpa terjadi bias atau mampu memperkecil kemungkinan terjadinya bias.

\section{SIMPULAN}

Angka kejadian balita stunting dalam penelitian ini adalah sebesar 36,21\%. Semua subjek penelitian memiliki kadar seng rambut normal dengan rata-rata kadar seng balita stunting 198,32 \pm 55,67 ppm dan balita normal 198,77 \pm 46,84 ppm. Tidak terdapat hubungan antara kadar seng $(\mathrm{Zn})$ rambut dengan $z$-score $\mathrm{PB} / \mathrm{U}$.

\section{UCAPAN TERIMA KASIH}

Puji syukur penulis panjatkan kehadirat Allah SWT, atas rahmat dan segala kemudahan yang telah diberikan. Terima kasih kepada orang tua dan keluarga atas doa serta dukungannya. Terima kasih kepada Dosen penguji dan pembimbing atas kritik dan saran yang diberikan. Terimakasih kepada Kepala Puskesmas Bugangan Kecamatan Semarang Timur, seluruh balita dan orang tua subjek yang berperan dalam penelitian ini.

\section{DAFTAR PUSTAKA}

1. Abas B,Jahari,ArumAtmawikarta,Atmarita,Dini Latief, Drajat, Endang,dkk.Pedoman Perencanaan Program Gerakan Nasional Sadar Gizi dalam Rangka Seribu Hari Pertama Kehidupan (Gerakan 1000 HPK).Republik Indonesia 2012.

2. K. Ryan Wessells, Kenneth H. Brown. Estimating the Global Prevalence of Zinc Deficiency: Results Based on Zinc Availability in National Food Supplies and the Prevalence of Stunting. Department of Nutrition, University of California Davis, Davis, California, United States of America.2012.

3. Departemen Kesehatan Republik Indonesia.Studi Masalah Gizi Mikro di 10 Propinsi, Pusat Penelitian dan Pengembangan Gizi dan Makanan (P3GM) Bogor. 2006.

4. Sareen S.G,Jack L,James L.Groff.Advanced Nutrition And Human Metabolism Fifth Edition. Wadsworth.Belmont,CA 94002-3098 USA.2009.

5. Lita Dwi Astari, Amini Nasoetion, Cesilia Meti Dwiriani. Hubungan Konsumsi ASI dan MP-ASI Serta Kejadian Stunting Anak Usia 6-12 Bulan di Kabupaten Bogor. Media Gizi dan Keluarga.2006. 30 (1) $15-23$.

6. Brown, K.H., et al., International Zinc Nutrition Consultative Group (IZiNCG) technical document Assessment of the risk of zinc deficiency in populations and options for its control. Food Nutr Bull, 2004. 25(1 Suppl 2): p. S99-203.

7. Manary, M. J. \& Solomons, N. W.Gizi Kesehatan Masyarakat, Gizi dan Perkembangan Anak. Penerbit Buku Kedokteran EGC. Terjemahan Public Health Nutrition, Editor. Gibney, M.J, Margetts, B.M., Kearney, J.M. \& Arab, L Blackwell Publishing Ltd, Oxford.2009.

8. World Health Organization.WHO Child Growth Standards. Geneva.2006.

9. United Nation System Standing Committee on Nutrition (UNSCN).Fifth Report On The World Nutrition Situation. Geneva : SCN.2004.

10. Deanna K.Olney, Ernesto Pollitt, Patricia K.Kariger, Sabra S.Khalfan, Nadra S.Ali, James M.Tielsch.Young Zanzibari Zhildren with Iron Deficiency, Iron Deficiency Anemia, Stunting, or Malaria Have Lower Motor Activity Scores and Spend Less Time in Locomomotion.American Society for Nutrition. 2007.

11. United Nation System Standing Committee on Nutrition (UNSCN).6th Report on The World Nutrition Situation Progress In Nutrition Situation.Geneva : SCN.2008.

12. Kementrian Kesehatan Republik Indonesia.Riset Kesehatan Dasar 2010. Badan Penelitian dan Pengembangan Kesehatan, Kementerian Kesehatan RI.2010. 
13. Tim Pemantauan Status Gizi (PSG) Keluarga Sadar Gizi (Kadarzi) Jawa Tengah.Pedoman Penyusunan Rencana Aksi Daerah Pangan dan Gizi (RAD-PG) Provinsi Jawa Tengah tahun 20112015.Semarang.2010.

14. Sulistijani,D.A.,Herlianty M.P.Menjaga kesehatan bayi dan balita.Jakarta : Puspa Swara.2001.

15. Roi David.Hubungan Asupan Makanan dengan Status Gizi Anak Usia 1-3 Tahun di Posyandu Balita Pos Balai Desa Plumpang Tuban.Stikes Yayasan Rumah Sakit Islam Surabaya.2012

16. Pongou R, Salomon JA, Ezzati M. Health impacts of macroeconomic crises and policies : determinants of variation in childhood malnutrition trends in Cameroon. International Journal of Epidemiology 2006 Jun; 35(3):648-656. Available from: URL: www.bvsde.paho.org

17. Zakout,Z.R.The Relationship Between Stunting and Zinc Deficiency Among Toddlers Aged 1-3 Years in Gaza Strip.Al-Azhar University-Gaza Faculty of Pharmacy Clinical Nutrition Program.2010.

18. Taufiqurrahman.Defisiensi Vitamin A dan Zinc Sebagai Faktor Risiko Terjadinya Stunting pada Balita di Nusa Tenggara Barat.Media Penelitian dan Pengembangan Kesehatan Volume XIX.2009.

19. Lowe NM,Fekete K, Decsi T.Methods of Assessment of Zinc Status in Humans: a Systematic Review.Am J Clin Nutr 2009;89(suppl):2040S-51S.

20. Huwae FJ.Hubungan Antara Kadar Seng (Zn) dengan Memori Jangka Pendek pada Anak Sekolah Dasar.[Tesis].Semarang:Universitas Diponegoro.2006.

21. Arindha Rahmawati, Yekti Wirawanni.Perbedaan Kadar Seng (Zn) Rambut Berdasarkan Derajat Stunting pada Anak Usia 6-9 Tahun.Program Studi Ilmu Gizi Fakultas Kedokteran Universitas Diponegoro Semarang.Journal of Nutrition College,volume 1,nomor 1,2012.hal 12-25

22. Dinas Kesehatan Kota Semarang.Laporan Pemantauan Status Gizi Kota Semarang.2011.

23. Gladys Gunawan,Eddy Faflyana,Kusnandi Rusmil.Hubungan Status Gizi dan Perkembangan Anak Usia 1-2 tahun.Sub Bagian Tumbuh Kembang Pediatri Sosial-Bagian SMF Ilmu Kesehatan Anak Fakultas Kedokteran Universitas Lambungmangkurat/RSUD

Ulin,Banjarmasin.2011.

24. Riset Kesehatan Dasar.Pedoman pengukuran dan pemeriksaan.Badan Penelitian dan Pengembangan Departemen Kesehatan RI. Jakarta.2007.

25. Suhartini. Tahap perkembangan motorik bayi. FKIK Universitas Negeri Yogyakarta.2005.

26. Gibson RS. Principle of Nutritional Assessment.Second edition.Oxford University Press.2005.p.380..

27. Yasar U, Ozyigit. Use of Human as a Potential Biomonitor for Zinc in the Pendik District Istanbul
Turkey. Roumanian Society of Biological Sciences. 2009;14(3):4477-84.

28. Riswandri.Kebiasaan Membuka Jendela Rumah,Jumlah Anggota Keluarga dan Letak Ternak Kandang Berhubungan dengan Kejadian ISPA di Kecamatan Parung-Jawa Barat.Jawa Barat.Karya Tulis Ilmiah.2002.

29. Golden M H. Proposed recommended nutrient densities for moderately malnourished children. Food and Nutrition Bulletin, vol 30, no 3. 2009.

30. Mahan LK, Sylvia ES. Krause's Food and Nutrition Therapy. 12th ed. Canada: Saunders Elsevier; 2008.

31. Listyani Hidayati,Hamam Hadi,Amitya Kumara.Kekurangan Energi dan Zat Gizi Merupakan Faktor Risiko Kejadian Stunted pada Anak Usia 1-3 Tahun Yang Tinggal di Wilayah Kumuh Perkotaan Surakarta. Jurnal Kesehatan, ISSN 1979-7621, Vol. 3, No. 1, Juni 2010: 89-104

32. Biolab Medical Unit. Hair Mineral Analysis. Nutritional and Environtmental Medicine. England.September.2012. 